\title{
DAKWAH JAMAAH TABLIG DALAM MEMBENTUK KELUARGA SAKINAH
}

\author{
Fristia Berdian Tamza \\ Universitas Islam Negeri Raden Intan Lampung, Indonesia \\ frestiaberdian@gmail.com
}

\author{
Ahmad Rajafi \\ Institut Agama Islam Negeri Manado, Indonesia \\ ahmad.rajafi@gmail.com
}

\begin{abstract}
Abstrak. Dakwah bi al-hal biasa dilakukan oleh jamaah tablig di dunia, mereka keluar dari rumah-rumah mereka dan kemudian mendakwahkan Islam dengan konsep al-khuruj. Konsep pencariaan jati diri melalui khuruj tersebut ternyata digunakan pula dalam membentuk keluarga sakinah. Khuruj mampu menempa mental dan spiritual bahkan jasmani dari setiap anggota jamaah tablig. Dengan khuruj, ketulusan suami-istri dalam membangun keluarga hanya semata-mata karena Allah Swt., sehingganya ketika terjadi masalah dalam rumah tangga, cukup dikembalikan kepada Allah semata, dengan jalan zikir dan dan doa. Tidak dapat dipungkiri kalau mereka masih sering menggunakan hadishadis yang berbau misoginis. Hal ini terjadi karena mereka berusaha untuk selalu konsisten menerapkan cara hidup yang hanya didasarkan dengan al-Quran dan al-hadis dan tidak begitu memperhitungkan kondisi sosial masyarakat yang ada sekarang ini.
\end{abstract}

Kata Kunci: Dakwah, Jamaah Tablig, Keluarga Sakinah

Abstrack: The bi al-hal da'wah is commonly conducted by the Tablig pilgrims. They leave their homes to teach Islam using the concept of al khuruj. The concept of personal identity search through khuruj is in fact, also applied in establishing a sakinah family. Khuruj can forge every member's mentality, spirituality and phisical. Through khuruj, husband-wife sincerity in their family is solely for Allah Swt. Thus, whenever a problem occur in their household, they will simply turn it to Allah through dzikir and du'a. It cannot be ignore the fact that they often used misogynous hadis. This is due to their persistence to adopt a way of life which is strictly based on a Qur'an and al hadis while at the same time, neglecting the current society social conditions.

Key Words: Da'wah, Tablig pilgrims, Sakinah family 


\section{A. Pendahuluan}

Keluarga merupakan lingkungan budaya pertama dan utama dalam rangka menanamkan norma agama dan mengembangkan berbagai perilaku yang dianggap penting bagi kehidupan pribadi, keluarga dan masyarakat di masa depan. Model dan gaya hidup sebuah keluarga banyak bergantung pada tingkat pendidikan dan penghayatan anggotanya terhadap norma agama dan hukum yang berlaku.

Masyarakat yang mayoritas penduduknya kaum terdidik akan relatif bertenggang rasa dan bertanggung jawab dibandingkan dengan masyarakat yang tidak terdidik ketika berinteraksi sosial dengan masyarakat luas. Demikian pula, masyarakat religius akan lebih agamis merefleksikan perkataan dan tindakan dalam kehidupan sosial-kemasyarakatan dibandingkan dengan masyarakat abangan, dan masyarakat industri akan lebih borjuis dalam bergaya hidup dibandingkan dengan masyarakat agraris. ${ }^{1}$

Hidup berumah tangga merupakan tuntutan fitrah manusia sebagai makhluk sosial. Keluarga atau rumah tangga muslim adalah lembaga terpenting dalam kehidupan kaum muslimin umumnya dan manhaj amal Islami khususnya. Ini semua disebabkan karena peran besar yang dimainkan oleh keluarga, yaitu mencetak dan menumbuhkan generasi masa depan, pilar penyangga bangunan umat dan perisai penyelamat bagi negara. ${ }^{2}$

Tidak berlebihan apabila dikatakan bahwa keluarga merupakan pondasi awal dari bangunan masyarakat dan bangsa. Keselamatan dan kemurnian rumah tangga adalah faktor penentu bagi keselamatan dan kemurnian masyarakat, serta sebagai penentu kekuatan, kekokohan,

Musthafa Masyhur, Qudwah di Jalan Dakwah, terjemah oleh Ali Hasan, (Jakarta: Citra Islami Press, 1999), h. 71 dan keselamatan dari bangunan negara. Apabila bangunan sebuah rumah tangga hancur maka sebagai konsekuensi logisnya masyarakat serta negara bisa dipastikan juga akan turut hancur.

Seorang suami dan atau ayah dalam berumah tangga mempunyai tanggung jawab terhadap keluarga yang dipimpinnya, laki-laki sebagai seorang muslim juga mempunyai tugas yang tidak kalah pentingnya dan merupakan tugas pokok setiap muslim untuk melakukan. Sesuai firman-Nya:

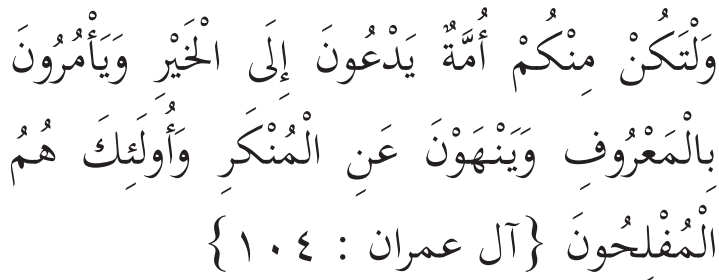

Artinya : "Dan hendaklah ada di antara kamu segolongan umat yang menyeru kepada kebajikan, menyuruh kepada yang makruf dan mencegah dariyang mungkar; merekalah orang-orang yang beruntung." (QS. Ali 'Imran: 104)

Perintah untuk amar makruf dan nahi mungkar ini di dalam al-Quran disebutkan di beberapa surat, antara lain; Ali Imran (3): 3 dan 114; an-Nisa' (4): 114; al-Maidah (5): 63, 78, 79; al-An'am: 69; al-A'rāf (7): 157, 165, 199; al-Taubah (33): 67, 71, 112; Hud (11): 116; alNahl (16): 90; Maryam (19): 55; al-Hajj (22): 41, 77; an-Nur (24): 21; Luqman (31): 17; adzDzariyat (51): 55; al-A'la (87): 9.

Amar makruf dan nahi mungkar diperintahkan untuk dikerjakan di manapun dan kapan pun seorang muslim berada dan kepada siapa pun perlu dilakukan. Akan tetapi menjadi berbeda jika konteks amar makruf dan nahi mungkar yang diprakarsai oleh keluarga jamaah tablig yang memiliki frame "kolot" dalam masyarakat. Di sinilah pentingnya menelaah pola kerja dakwah mereka dalam rangka pem- 
bentukan keluarga sakinah. Untuk masa kini, kelompok atau jamaah muslim yang memfokuskan diri bekerja di sektor dakwah atau "bengkel keimanan" yang cukup besar di Indonesia adalah jamaah tablig. ${ }^{3}$

Konsep dakwah mereka dalam menempa mental-mental jamaahnya menjadi lebih baik, termasuk mereka dalam rangka pembentukan keluarga sakinah dengan memunculkan semangat kemandirian yang tinggi bagi para jamaahnya. Gerakan dakwah mereka mengandalkan biaya sendiri dan meluangkan waktunya untuk bertablig ke berbagai penjuru desa, kota bahkan manca negara dalam jangka waktu tertentu antara 3-40 hari, 4-7 bulan bahkan setahun yang mereka biasa menyebutnya dengan khuruj fi sabilillah. Itu semua dilakukan oleh mereka dengan meninggalkan keluarganya dan semua kesibukan yang sifatnya duniawi. ${ }^{4}$

Kegiatan-kegiatan mereka bertujuan untuk mewujudkan mentalitas keislaman yang baik dan konsisten sesuai dengan ajaran dan yang dilakukan oleh Nabi Muhammad saw., sehingga terkadang apa yang dilakukan oleh anggota jamaah tablig di lingkaran masyarakat dinggap ketinggalan zaman terutama masalah yang berhubungan dengan keseimbangan hak dan kewajiban di dalam rumah tangga.

Maulana Muhammad Ilyas berpendapat, setiap orang Islam baik laki-laki maupun perempuan harus mengikuti jejak langkah Nabi Muhammad saw., mereka harus menyeru manusia ke jalan Allah, kapan saja ada kesempatan untuk melakukan hal tersebut di hadapannya. Menyeru manusia ke jalan yang benar mestilah dijadikan tugas dalam kehidupannya. Maka sudah sepantasnya kalau mengaku sebagai

Husein bin Muhsin bin 'Ali Jabir, Membentuk Jama'atul Muslimin, alih bahasa oleh Supriyanto (Jakarta: Gema Insani Press, 1998), h. 223

4 Muhammad Qowim dkk, Model Dakwah Jama'ah Tablig, Laporan Penelitian Kelompok Mahasiswa Pasca Sarjana IAIN Sunan Kalijaga Yogyakarta, (Yogyakarta: Perpustakaan Pasca Sarjana, 2002), h. 10 umat Muhammad saw. harus meneruskan tugas Beliau ber-amar makruf nahi mungkar yang komplit. $^{5}$

Maulana Muhammad Ilyas berpendapat, diperlukan upaya khuruj, yaitu keluar rumah meninggalkan segala kesibukan duniawi dengan jangka waktu tertentu untuk meningkatkan keagamaannya. Berdakwah dengan cara berkeliling (jaulah) merupakan sebuah keharusan, karena itu berarti tugas dakwah merupakan tugas setiap umat Islam secara individual, bukan diserahkan kepada institusi atau lembaga yang bergerak di bidang dakwah saja.

Amalan jaulah merupakan tulang punggung dalam menjalankan tugas-tugas jamaah. Jika amalan ini benar dan sesuai dengan aturan yang ditetapkan oleh jamaah niscaya amalan ini diterima oleh Allah Swt., dan berimplikasi pada perubabahan mental-spiritual para pelakunya, bahkan mereka yang dianggap "preman" dan pecandu narkoba mampu mentransformasi pribadinya hingga 180 derajat, menjadi muslim yang baik. Menurut Maulana Ilyas, hal tersebut merupakan bukti jawaban Allah atas amaliah hambanya, jika Allah menerima dakwah seseorang, niscaya Allah juga akan menerima doa mereka sehingga Dia akan menurunkan hidayah-Nya. ${ }^{6}$

Demikianlah pentingnya tanggung jawab seorang muslim terhadap kehidupannya di dunia sebagai hamba Allah yang dipercaya memikul predikat khalifah fî al-ardh, khususnya dalam beberapa hal yang berkaitan dengan tanggung jawab jamaah terhadap keluarganya dan tanggung jawabnya sebagai muslim yang konsekuen terhadap perintah agamanya (di jalan Allah). Atas dasar nalarisasi tersebut, maka bagaimanakah sebenarnya konsep dakwah menuju keluarga sakinah mereka da-

Furqon Ahmad Anshari, Pedoman Bertablig Bagi Umat Islam, ed. Supriyanto Abdullah, (Yogyakarta: Ash-Saff, 2000), h. 37 
lam menyikapi situasi dan kondisi yang mereka hadapi dan yang mereka kerjakan.

Pertanyaan besar tersebut merupakan respon sosial atas kegiatan dakwah mereka yang dianggap bertentangan dengan makan sakinah itu sendiri. Secara definitif, penggunaan nama sakinah diambil dari ayat al-Quran surat ar-Ruum ayat 21, litaskunu ilaiha, yang artinya bahwa Tuhan menciptakan perjodohan bagi manusia agar yang satu merasa tenteram terhadap yang lain. Dalam bahasa Arab, kata sakinah di dalamnya terkandung arti tenang, terhormat, aman, penuh kasih sayang, mantap dan memperoleh pembelaan. Pengertian ini pula yang dipakai dalam ayat-ayat al-Quran dan hadis dalam kontek kehidupan manusia. Jadi, keluarga sakinah adalah kondisi yang sangat ideal dalam kehidupan keluarga, dan yang ideal biasanya jarang terjadi. Ia tidak terjadi mendadak, tetapi ditopang oleh pilarpilar yang kokoh, yang memerlukan perjuangan serta butuh waktu serta pengorbanan terlebih dahulu. Oleh karena itu, konsep dakwah jamaah tablig dalam membentuk keluarga sakinah adalah tema besar yang akan diteliti di dalam paper ini.

\section{B. Konsep Keluarga Sakinah}

Dalil utama keluarga sakinah bagi komunitas jamaah tablig tidak berbeda dengan pemahaman umum umat Islam, yakni:

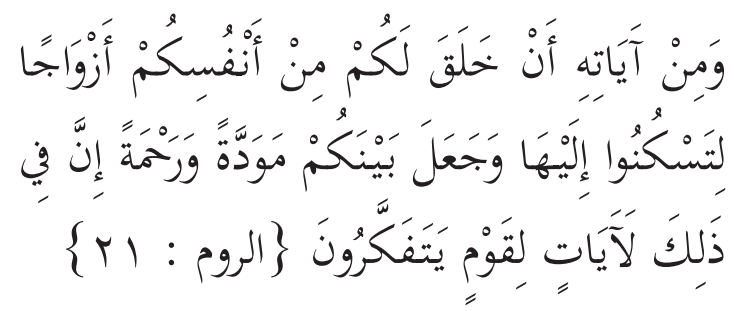

Artinya : "Dan di antara tanda-tanda kekuasaan-Nya ialah Dia menciptakan untukmu isteri-isteri dari jenismu sendiri, supaya kamu cenderung dan merasa tenteram kepadanya, dan dijadikan-Nya di antaramu rasa kasih dan sayang. Sesungguhnya pada yang demikian itu benar-benar terdapat tanda-tanda bagi kaum yang berpikir." (QS. ar-Ruum : 21)

Ayat tersebut menjadi dalil utama pembentukan keluarga sakinah, di mana pemahaman yang diambil oleh mereka adalah dengan jalan tekstualitas nass, bukan memahami pada sisi konteks dan substansi atas ayat-ayat tersebut. Bagi mereka, ayat tersebut ditunjukkan kepada laki-laki sebagai calon kepala keluarga di mana melalui dirinya akan dihadirkan oleh Allah pasangan yang mampu untuk menemaninya (litaskunu), sehingga menghadirkan rasa cinta (mawaddah) terhadap pasangannya dan dicurahi rahmat (rahmah) Allah Swt. kepada pasangan tersebut.

Pada sisi ini, pemikiran jamaah tablig bersifat tradisional melalui transmisi keilmuan yang diraih di dalam komunitas itu sendiri. Ulama bagi mereka adalah segala-galanya, akan tetapi yang dimaksud dengan ulama di sini adalah mereka yang betul-betul menyibukkan diri di dalam dakwah atau tablig. Artinya, ulama yang berada di luar komunitas tersebut tidak tercantum di dalam daftar rujukan ulama bagi mereka. Kecuali hanya sebagai bahan sekunder atau bahkan bahan tersier.

Penjelasan yang disampaikan para ulama jamaah tablig selalu diulang-ulang sehingga hampir keseluruhan jamaah mampu untuk menghafalnya tanpa harus melakukan penjelasan apalagi mengkritisi penjelasan tersebut. Walhasil dalam hal konsep keluarga sakinah, suami menjadi sentral utama dengan istri sebagai masyarakat kelas dua yang bertugas untuk mengurus rumah tangga dan anak-anak. Dalil penguatnya adalah sebagai berikut.

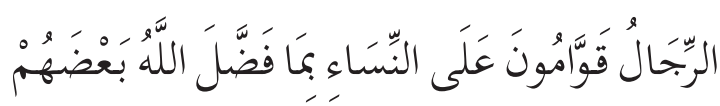




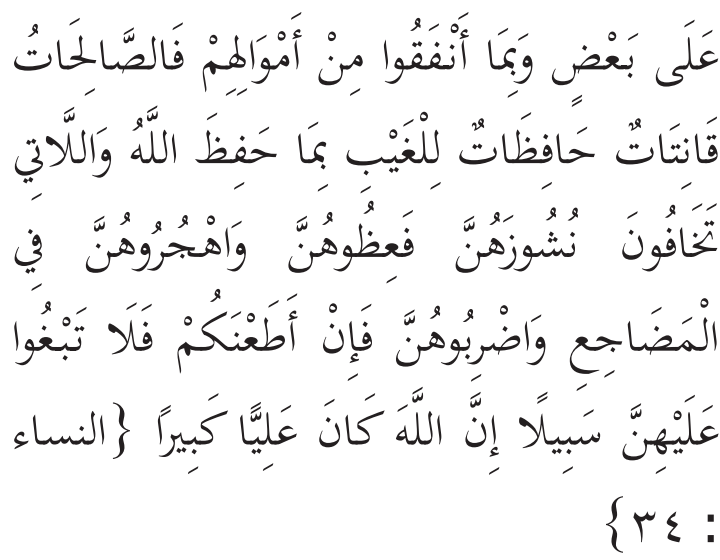

Artinya : "Kaum laki-laki itu adalah pemimpin bagi kaum wanita, oleh karena Allah telah melebihkan sebahagian mereka (laki-laki) atas sebahagian yang lain (wanita), dan karena mereka (lakilaki) telah menafkahkan sebagian dari harta mereka. Sebab itu maka wanita yang saleh, ialah yang taat kepada Allah lagi memelihara diri ketika suaminya tidak ada, oleh karena Allah telah memelihara (mereka). Wanita-wanita yang kamu khawatirkan nusyuznya, maka nasihatilah mereka dan pisahkanlah mereka di tempat tidur mereka, dan pukullah mereka. Kemudian jika mereka mentaatimu, maka janganlah kamu mencari-cari jalan untuk menyusahkannya. Sesungguhnya Allah Maha Tinggi lagi Maha Besar." (QS. an-Nisa' : 34)

Atas dasar tekstualitas kedua ayat di atas, mereka mengimani bahwa laki-lakilah yang harus memimpin di dalam rumah, sehingga istri harus tunduk dan patuh kepada suami secara mutlak. Ketika seorang istri menjalankan berbagai aktivitas maka harus melalui izin suami, bahkan dalam urusan agama sekalipun. Untuk mendapatkan pasangan yang mampu mengimplementasikan itu semua, maka harus didahului dengan pencarian jodoh yang sesuai tekstulitas hadis Rasulullah saw.;

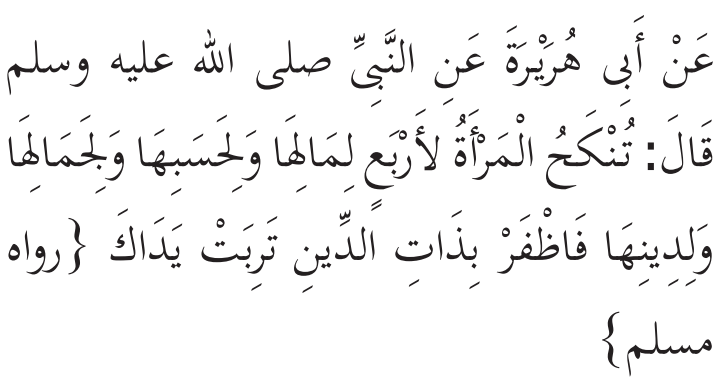

Selain itu, hadis yang disampaikan oleh Anas bin Malik juga Ali bin Abi Thalib r.a. yang berisi tentang anjuran menikahi wanita yang banyak anaknya, dan lain sebagainya. ${ }^{7}$ Mereka juga menggunakan pendapatnya as-Sayyid Sabiq yang menyatakan sunnah bagi seorang pria yang ingin menikah untuk memilih wanita yang mempunyai kriteria sebagai berikut; 1 ) salihah (taat dalam menjalankan agamanya); 2) perawan; 3) keturunan orang saleh; 4) sayang kepada anak-anak; 5) cantik serta ringan maharnya; dan 6) tidak mandul. ${ }^{8}$

Alasan dari adanya kriteria di atas adalah apabila terpenuhi semua atau minimal tiga atau empat dari kelima kriteria yang ada, maka diprediksi rumah tangga tentunya akan tercipta keharmonisan dan kebahagiaan dunia dan akhirat. Sebagai perumpamaan dengan adanya ibu rumah tangga yang salihah lagi cantik yang juga keturunan orang saleh diharapkan akan lahir anak-anak yang shalih-salihah karena asal gatir keturunannya juga orang-orang saleh dan salihah.

Adapun anjuran memilih wanita yang perawan adalah karena diasumsikan ia belum berpengalaman hidup dengan lelaki lain (yang non-muhrim atau suaminya) sehingga kehidupan rumah tangga akan lebih indah dengan sifat

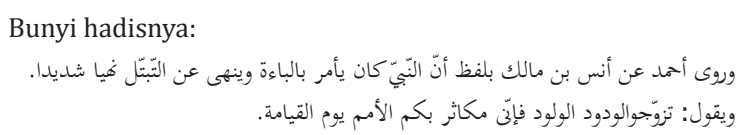

Bunyi hadisnya: وروى أحمد عن أنس بن مالك بلفظ أنّ النّبّ كان يأمر بالباءة وينهى عن التّبّل خهيا شديدا.

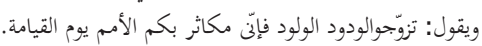

8 Abdurrahman Ahmad, Petunjuk Sunnah dan Adab Sehari-hari Lengkap, (Cirebon: Pustaka Nabawi, 2000), h. 114 
pemalunya wanita. ${ }^{9}$ Selain itu wanita yang sudah pernah menikah juga dianggap lebih reaksionis dibandingkan dengan wanita yang belum pernah menikah. Hal ini diasumsikan karena adanya trauma di dalam pernikahan yang dialami wanita (yang sudah pernah menikah) tersebut, dan seterusnya.

Konsep selanjutnya adalah tentang peminangan, bagi mereka dinyatakan bahwa syaratsyarat bolehnya melakukan peminangan, adalah; perempuan yang akan dipinang tidak dalam pinangan lelaki lain, dan perempuan yang akan dipinang tidak terhalang secara syara', seperti dalam masa 'iddah atau perempuan tersebut merupakan muhrim dari laki-laki yang akan meminangnya.

Sedangkan mengenai pembolehan melihat calon yang akan dipinang (nazhar) itu sebatas yang diperbolehkan agama dan tidak diperkenankan menyendiri berduaan saja. Karena apabila hanya berduaan saja tanpa adanya muhrimnya perempuan yang menemaninya dikhawatirkan akan terjadi hal-hal yang tidak diinginkan yang perbuatan tersebut bertentangan dengan ajaran agama. Bahkan dalam konteks yang lebih spesifik, jamaah tablig memiliki persepsi bahwa wajib hukumnya menjauhi cara-cara khitbah yang non-Islami seperti tukar cincin, dan lain-lain. Karena dengan melakukan atau meniru cara-cara yang non-Islami berarti digolongkan dengan mereka (orang-orang non-Islam). Konsepsi seperti ini sejalan dengan hadis yang menerangkan:

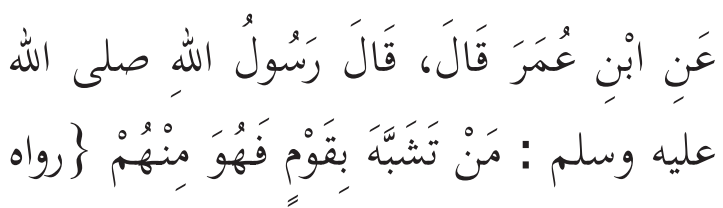

Wanita yang sudah pernah menikah biasanya sifat pemalunya sudah agak berkurang ketika berhadapan dengan lelaki lain. Hal ini dianggap wajar karena wanita yang sudah pernah menikah lebih berpengalaman di dalam hidupnya (dalam hal ini berkenaan dengan kebiasaan berinteraksi).

$$
\text { أبوا داودد }
$$

Artinya : "Dari Ibnu Umar berkata, Rasulullah saw. bersabda; Barang siapa meniru-niru suatu kaum maka ia tergolong dalam kelompok mereka." (HR. Abu Dawud).

Pada konteks ini, nalarisasi yang ditarik oleh jamaah tablig bersifat tekstual, dan menafikan realitas hukum Islam yang dibangun atas dasar budaya atau adat-istiadat masyarakat lokal (local wisdom). Seperti dalam hal nazhar misalnya, tema kajian fikih yang hidup di dalam masyarakat Arab pra-Islam yang kemudian turut diakui dan direvisi di dalam Islam tersebut tentunya tidak serta merta dapat diterapkan di dalam masyarakat muslim non-Arab, seperti Indonesia. Masyarakat Indonesia memiliki adat istiadat yang tidak terbuka seperti masyarakat Arab, sehingganya terma nazhar akan menjadi sesuatu yang kaku untuk diterapkan di Indonesia.

Masyarakat muslim Indonesia tidak mengenal adanya penutup wajah seperti yang hidup dalam budaya masyarakat Arab-Islam. Pakaian yang dikenakan oleh seorang muslimah di Indonesia masuk ke dalam tatanan kelayakan atau kesopanan yang hidup di dalam masyarakat Indonesia, baik dengan menggunakan jilbab ataupun dengan hanya menggunakan penutup kepala seperti kerudung. Bahkan kontak sosialnya pun berlaku bebas namun beretika. Pria muslim dan muslimah bisa bertemu di mana saja dan kapan saja sehingga dapat terlihat wajah dan bahkan kepribadian mereka. Untuk itu, ketentuan melihat calon pasangan menjadi tidak relevan dalam konteks Islam Indonesia.

10 Hadis di atas menurut Albani tergolong berkualitas hasan shahih, lihat Sulaiman bin al-Asy'ats Abu Dawud al-Sajistani, Sunan Abi Dawud, (Beirut: Dar al-Fikr, t.th.), Juz. 2, h. 441 
Bagitu juga dengan masalah khithbah yang tidak bisa tidak terjadinya percampuran budaya (akulturasi) di dalamnya. Yakni percampuran antara budaya Arab-Islam dengan budaya lokal yang ada di wilayah NKRI (Negara Kesatuan Republik Indonesia). Seperti adanya tukar cincin, pingitan, nyekar, ataupun siraman sebelum terjadinya proses pernikahan. Bangunan hukum tentang adat budaya tersebut dalam formulasi hukum Islam dikenal dengan istilah al-'urf, yang memiliki makna:

$$
\begin{aligned}
& \text { ما اعتاده الناس و ساروا عليه من كل فعل شاع } \\
& \text { بينهم أو لفظ تعارفوا إطلاقه على معنى خاص } \\
& \text { لا تألفه اللغة ولا يتبادر غيره عند سماعه.'” }
\end{aligned}
$$

Artinya : "Kebiasaan masyarakat yang telah berlangsung, baik dari segi perilaku yang hidup di antara mereka ataupun ungkapan yang diketahui bersama secara khusus oleh mereka dan tidak ada di dalam kamus bahasa serta belum pernah didengar selain mereka."

Kaidah yang menopang terma 'urf tersebut di dalam hukum Islam adalah:

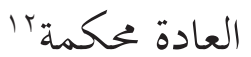

Artinya : "Adat kebiasaan adalah bagian dari hukum."

Dalil utamanya adalah hadis Rasulullah Muhammad saw. yang diriwayatkan oleh Imam Malik:

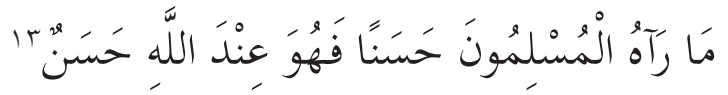

11 Wahbah Zuhaili, Ushul al-Fiqh al-Islami, (Damaskus: Dar al-Fikr, 1986), Juz. 2, h. 828

12 'Abd al-Malik bin 'Abdullah bin Yusuf al-Juwaini Abu al-Ma'ali, alBurhan fi Ushul al-Fiqh, (Mesir: al-Wafa', 1418 H), Cet. Ke-4, Juz. 1, h. 377

13 Malik bin Anas Abu 'Abdillah al-Ashbahi, Muwaththa' al-Imam Malik, (Damaskus: Dar al-Qalam, 1991), Juz. 1, h. 355
Artinya : "Hal baik dalam pandangan manusia, turut bernilai baik di hadapan Allah Swt."

Atas dasar ketentuan noramatif tersebut, maka apa yang diimani oleh jamaah tablig tentang membangun keluarga sakinah pada konteks pra-akad sangat kontra produktif. Terlebih lagi bahwa substansi dari hukum Islam adalah jalb al-mashalih wa dar'u al-mafasid (membangun kemaslahatan dan mencegah kerusakan). Dengan demikian, tekstualitas pemikiran jamaah tablig tersebut perlu ditinjau ulang dalam rangka menciptakan citra Islam beserta ketentuan hukumnya yang responsif di tengah-tengah masyarakat atau berkesesuaian dengan kearifan lokal (local wisdom).

Selanjutnya, setelah berlangsungnya akad nikah, maka ikatan suami-istri telah berlaku pada diri mereka berdua. Di saat itulah diberlakukan aturan-aturan antara masing-masing pihak demi terbentuknya keluarga sakinah di dalam hubungan mereka. Pada bagian awal, tema utama berada pada pembinaan suami melalui cara yakni meneladani kehidupan Rasulullah Muhammad saw. dan para sahabat r.a.

Pola ittiba' berada pada ketentuan untuk mengikuti seluruh pribadi baginda Rasulullah saw. baik dari mulai fisik, aksesoris, hingga amaliah hati dan jasmaninya. Bentuk fisik yang popular adalah memanjangkan jenggot, bercelak di mata, selalu berkopiah haji dan menggunakan saal dikepala, dan selalu memakai jubah atau gamis. Dalam hal mengikuti perilaku keseharian baginda Rasulullah saw., amaliahnya adalah seperti selalu bersiwak dengan kayu siwak sebelum berwudu, selalu memakai minyak wangi yang tidak beralkohol sebelum melaksanakan salat, merapatkan saf sebelum dimulainya ibadah salat, dan lain-lain. 
Untuk mengisi hati dengan cahaya Allah, maka dirutinkan untuk terus menjalankan salat sunnah rawatib di setiap lima waktu, merutinkan salat malam (tahajud) dan dhuha, dan tidak pernah lepas untuk terus berzikir, mendekat dengan masjid dan orang-orang yang berilmu dan ahli zikir. Untuk mendapatkan hal tersebut, dianjurkan bagi setiap anggota jamaah untuk keluar (khuruj) di jalan Allah minimal tiga hari.

Jalan khuruj merupakan metode yang efektif menempa mental dan spiritual untuk menjadi pribadi-pribadi yang mencintai Rasulullah saw. dan berimplikasi pada lahirnya keluarga sakinah. Bahkan dalam hal khuruj tersebut pun ada cara yang dianggap oleh mereka betul-betul mengikuti dakwah Rasulullah saw., yakni dengan cara berjalan kaki atau tanpa fasilitas kendaraan menuju objek-objek dakwah untuk mendakwahkan Islam.

Setiap anggota jamaah yang khuruj harus mampu menanamkan nilai-nilai kesabaran dalam menempa emosinya, mampu berkomunikasi dengan orang lain untuk menempa sisi sosialnya, berolahraga di setiap pagi untuk menyehatkan tubuhnya, dan bangun di malam hari untuk menempa sisi spritualnya. Atas dasar khuruj tersebutlah kemudian seorang suami akan meraih pelajaran berharga untuk kemudian ditransfer ke dalam rumahnya. Ia harus mampu menjadi imam yang dapat diterima oleh seluruh anggota keluarganya, istri harus dapat mendukung suami dan menjaga amanah keluarga, serta anak-anak harus mampu menjadi permata hati bagi ayah dan ibunya.

Konsepsi khuruj yang harus dibawa ke dalam rumah adalah; Pertama, pentingnya untuk mengajarkan kepada keluarga tentang keutamaan berserah diri kepada Allah Swt. dengan menanamkan kalimah thayyibah yakni La Ilaha Illa Allah Muhammad Rasulullah di dalam hati dan jiwanya serta terefleksi di dalam kepibadiannya.

Melalui konsep ini, antara suami dan istri tidak akan saling memaksakan kehendak antara satu sama lainnya, keduanya akan takluk di dalam kehendak Allah Swt. Istri akan selalu qana'ah (menerima dengan lapang dada) terhadap pengahasilan suaminya yang diserahkan kepadanya dan kemudian dikelola olehnya. Bagi mereka, visi sakinah mawaddah dan rahmah tidak akan pernah terwujud jika istri merasa lebih besar dari suaminya, atau suami merasa segala-galanya di hadapan istrinya.

Kedua, yakni prinsip untuk selalu mengajak seluruh anggota keluarga agar selalu berzikir dan beribadah kepada Allah Swt. Mengimplementasikan zikir terangkum dalam kerja lisan, hati dan perbuatan. Semuanya berupaya untuk menyebut-nyebut Allah sebagai bukti mengingat-Nya. Pengajaran tentang zikir diawali dengan mencoba untuk membaca wirid-wirid tertentu dari jumlah akumulasi yang minimal hingga berkelanjutan pada jumlah yang tidak terhingga. Contohnya adalah membaca sayyidul istighfar ${ }^{14}$ dari mulai sepuluh kali, kemudian seratus kali hingga pada jumlah yang dinggap banyak seperti seribu kali atau seratus ribu kali.

Begitu juga dengan ibadah, setiap individu di dalam keluarga harus diajarkan secara bertahap tentang menambah kualitas ibadah melalui penambahan jenis dan jumlah rakaat salat. Dari yang tidak biasa salat duha menjadi harus terbiasa, diawali dengan hanya dua rakaat saja hingga berkelanjutan dan terbiasa untuk jumlah yang lebih tinggi yakni delapan rakaat.

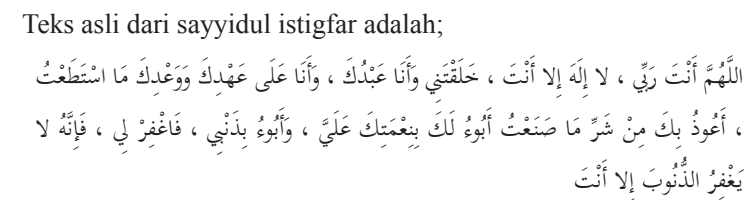

Lihat Muhammad bin Isma'il Abu 'Abdillah al-Bukhari, al-Jami' ash-Shahih al-Mukhtashar, (Beirut: Dar Ibn Katsir, 1987), Juz. 5, h. 2323 
Fungsi dari peningkatan kualitas zikir dan ibadah bagi pasangan suami-istri adalah mempertebal sisi religiusitas anggota keluarga, khususnya pasangan dan anak-anak. Semakin tebal sisi religiusitasnya, maka semakin tebal pula ketundukannya terhadap ketentuanketentuan agama baik yang dalam hal ketaatan kepada Allah dan Rasul-Nya serta ketaatan kepada suami. Pada sisi ini, yang ditekankan implikasinya berada pada aspek tekstualitas yang ternyata berdampak positif bagi mereka.

Begitu juga dengan pola ta'lum dan ta'lim yakni berlajar dan mengajar, di mana setiap anggota jamaah harus mampu untuk belajar dengan dengan baik berbagai ajaran agama Islam, yang selanjutnya dijadikan sebagai bahan untuk didakwahkan (diajarakan) kepada kaum muslimin lainnya. Aspek di atas menekankan sisi edukasi, dengan mengantarkan anggota keluarga untuk menjadi pandai dan berpengetahuan laus dalam meraih urusan akhirat yang hakiki.

Implikasinya bagi keutuhan keluarga adalah pada sisi sakinah, yakni berkumpulnya kedua pasangan dengan penuh ketenangan. Sakinah hanya dapat dirasakan ketika masingmasing pasangan mengetahui ilmu tentang hak dan kewajiban masing-masing pasangan. Ilmu tersebut hanya dapat diraih ketika dipelajari dan mampu memahami sisi hakikatnya ketika

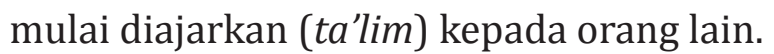

Konsep terakhir adalah khidmat yakni melakukan pelayanan. Pada aspek ini, pelayanan dilakukan dengan cara penuh keikhlasan dan semata-mata berharap rida Allah Swt. Bagi anggota jamaah, pelayanan atau khidmat tidak mengharapkan keuntungan dunia, karena keuntungan yang hakiki adalah datangnya dari Allah di akhirat kelak. Oleh kerena itu, jika ditarik pada materi keluarga sakinah, maka konsep khidmat mengarahkan pada setiap pa- sangan untuk betul-betul menggapai mawaddah (rasa cinta) dan rahmah (kasih sayang Allah) melalui pelayanan yang maksimal kepada pasangannya masing-masing. Bahkan demi melaksanakan khidmat tersebut, jamaah tablig wajib memahami seluruh dalil-dalil agama baik al-Quran maupun al-hadis dengan jalan tekstual bahkan terhadap hadis-hadis yang dianggap misoginis.

Menurut jamaah tablig, suami istri harus saling menghargai dan menghormati. Jika suami menuntut untuk diperlakukan dengan baik oleh istrinya, maka ia harus memulainya dari dirinya sendiri. Selain itu, seringkali juga dinyatakan bahwa kedudukannya istri bagaikan seorang tawanan bagi suaminya. Seorang istri harus lebih mendahulukan hak suaminya dibandingkan haknya sendiri, harus mematuhi suaminya di atas segala-galanya, karena ridanya suami merupakan ridanya Allah Swt.

Semua yang dilakukan istri selalu dibayangbayangi oleh laknat, entah itu laknatnya alam, malaikat, maupun Allah. Tidak dapat dipungkiri kalau mereka masih sering menggunakan hadis-hadis yang berbau misoginis. Kemungkinan karena mereka berusaha untuk selalu konsisten menerapkan cara hidup yang hanya didasarkan dengan al-Quran dan al-hadis dan tidak begitu memperhitungkan kondisi sosial masyarakat yang ada sekarang ini. Kebanyakan hadis-hadis misoginis tersebut menyangkut masalah kewajiban-kewajiban istri kepada suaminya, seperti jika istri tidak mau melayani ajakan suami untuk bersetubuh, ketika istri keluar rumah tanpa izin suami, ataupun misalnya sikap istri yang tidak menyenangkan di muka suaminya.

Hal ini mungkin akan terasa sebagai sebuah keadilan jika diperhatikan juga bagaimana kondisi istri saat-saat tersebut. Jika memang istrinya lagi dalam kondisi yang sedang tidak 
nyaman, tidak sehat, lelah mengurus rumah tangga, atau sedang tidak siap secara psikis, maka suami seharusnya tidak memaksakan kehendaknya. Karena secara psikologi, suamiistri tidak akan mencapai kepuasan seksual di saat salah satu pihak tidak dalam kondisi yang baik. Idealnya, suami dan istri harus berusaha saling memuaskan pasangannya.

Dalam hal ini seharusnya tidak hanya pihak istri saja yang selalu disalahkan, suami pun seharusnya dimintai tanggung jawabnya. Kalau memang suami sangat menginginkan kepuasan seksual secara sehat dan bersama-sama, maka sewajarnya ia berusaha bagaimana supaya gairah seksual istrinya terbangkitkan. Sehingga terhindar dari adanya yang memaksa dan yang dipaksa.

Adapun mengenai harta pribadi istri dinyatakan bahwa memang istri mempunyai hak penuh terhadap hartanya tersebut, akan tetapi untuk memakainya ia harus mendapat izin dari suaminya karena apapun yang dilakukan istri harus seizin suaminya. ${ }^{15}$ Pendapat mereka memang rasional bahwa seorang istri bebas membelanjakan harta pribadinya meskipun lebih baik istri memberitahu suaminya terlebih dahulu. Karena sesungguhnya mengenai harta tersebut adalah hak penuh atau hak mutlak istri yang tidak boleh dicampuri oleh suami. Bahkan menurut hukum Islam istri diperbolehkan untuk tidak mematuhi suaminya apabila ia diperintahkan oleh suaminya untuk membelanjakan hartanya dengan keinginan suaminya. ${ }^{16}$

Kembali ke masalah nafkah, memang suamilah yang mempunyai tanggung jawab penuh untuk mencukupinya. Meskipun istri bersedia untuk ikut membantu, akan tetapi itu tidak mengurangi kewajiban suami terhadap nafkah keluarganya tersebut. Menyinggung

\footnotetext{
Abdurrahman Ahmad, op.cit., h. 107

16 Ahmad Azhar Basyir, Hukum Perkawinan Islam, (Yogyakarta: UII press, 1999), h. 62
}

mengenai Jamaah Tablig, untuk berdakwah mereka harus mengeluarkan biaya sendirisendiri. Itu berarti, selain harus mencukupi nafkah keluarganya, anggota jamaah juga harus mengeluarkan biaya untuk kegiatannya tersebut.

Menurut mereka memang sebelum pergi khuruj suami biasanya sudah mempersiapkan biaya hidup keluarganya untuk jangka waktu selama suami pergi. Ini mungkin untuk keluarga yang termasuk dalam kelas ekonomi menengah ke atas karena biasanya selain mereka telah mempunyai tabungan juga penghasilan setiap bulannya cukup memadai untuk biaya hidup keluarganya dan untuk berdakwah. Dalam masalah khuruj, tidak ada kewajiban bagi orang yang tidak mampu, baik dari segi fisik ataupun finansialnya. Tetapi mereka juga tidak menyangkal kalau kegiatan tersebut seringkali membuat orang yang pernah ikut khuruj dan merasakan nikmatnya zikir dan taklim sehingga menjadikan kecanduan. Maka, biasanya yang terjadi pada orang yang broken home adalah tidak begitu memikirkan hal lain selain bagaimana caranya ia dapat memuaskan keinginannya. Memang tidak dapat dibuktikan datanya secara konkret, akan tetapi fakta dari kejadian tersebut telah ada, terjadi di daerah-daerah terutama di pedesaan. ${ }^{17}$

Dalam literatur klasik dinyatakan bahwa sebagai suami yang saleh seharusnya senantiasa melakukan yang terbaik bagi keluarganya, termasuk mengutamakan nafkah keluarga dalam membelanjakan hartanya di atas kepentingankepentingan yang lainnya. ${ }^{18}$ Suami juga hendak-

\footnotetext{
17 Beberapa fakta terjadi di daerah penyusun sendiri dan sekitarnya. Biasanya keluarga "korban” saling mengeluhkan kejadian yang dialami keluarganya kepada orang-orang yang dipercayainya. Menurut mereka, tidak hanya menghabiskan penghasilannya, bahkan sampai menjual barang-barang berharga lainnya yang dimilikinya seperti sawah, kebun, bahkan rumah.

18 Fuad Kauma \& Nipan, Membimbing Istri Mendampingi Suami, (Yogyakarta: Mitra Pustaka, 2003), h. 85-86
} 
nya pandai-pandai membelanjakan hartanya, mana yang lebih penting itulah yang didahulukan. Membelanjakan harta untuk sedakah di jalan Allah (termasuk untuk dakwah) adalah hal yang utama. Akan tetapi jika tidak mampu tidak ada kewajiban untuk memaksakan kehendak sehingga melupakan nafkan nafkah keluarga. ${ }^{19}$ Sabda Rasulullah Muhammad saw.:

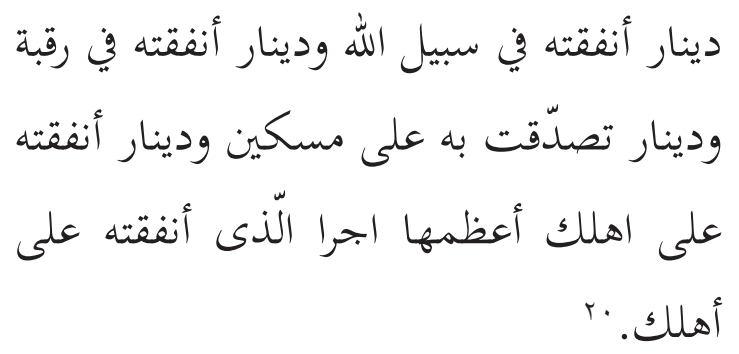

Mengenai hal tersebut, Allah Swt. telah menciptakan setiap manusia itu berpasangpasangan dengan tujuan supaya mereka (manusia) berumah tangga dan menjadikan keluarganya keluarga yang sakinah mawaddah wa rahmah. Keluarga yang sakinah adalah keluarga yang tercukupi secara material maupun spiritualnya (zahir maupun batinnya). Kedua kebutuhan tersebut harus diseimbangkan satu sama lainnya. Karena tidak akan tercipta ketenteraman rumah tangga jika salah satu unsurnya tidak terpenuhi.

Seperti hadis yang disampaikan oleh Anas r.a. bahwasanya ketika Allah menghendaki suatu keluarga menjadi individu yang mengerti dan memahami agama, yang lebih tua menyayangi yang lebih kecil dan sebaliknya, memberi rezeki yang berkecukupan di dalam hidup mereka, tercapai setiap keinginannya, dan menghindarkan mereka dari segala cobaan, maka

Ibid., h. 86

20 Ali Mubarak, Muhtasar Nailul Autar (Kairo: al-Mu'allaqāt asSalafiyyah, 1374 H), edisi Muammal Hamidi dkk, Terjemahan Nailul Autar (Surabaya: PT bina Ilmu, 1993), Jil. V, h. 2462. Hadis nomor 3867, "Kitab Nafaqah," "Bab Nafkah Istri Wajib Didahulukan Daripada Kerabat-kerabat Yang Lain". terciptalah sebuah keluarga yang dinamakan sakinah, mawaddah, warahmah. ${ }^{21}$

Selain kedua unsur itu, ada satu lagi unsur lain yang sangat mendukung akan terciptanya keluarga sakinah. Unsur tersebut adalah terciptanya keharmonisan hubungan sosial, karena manusia tidak bisa hidup tanpa uluran tangan dari orang lain, sepintar dan sekaya apapun dia. Manusia diciptakan di dunia sebagai mahluk sosial yang secara naluriah membutuhkan orang lain. Ia butuh saling mengenal satu sama lainnya sehingga terciptalah suasana tolong- menolong di antara mereka. Baik itu tolong-menolong dalam urusan dunia maupun tolong-menolong dalam urusan akherat. Tolong-menolong dalam urusan dunia contoh konkretnya seperti adat gotong-royong dalam menyelesaikan suatu pekerjaan yang tidak bisa diselesaikan sendiri seperti membuat rumah atau yang lainnya. Sedangkan contoh tolong-menolong dalam urusan akhirat seperti amar makruf dan nahi mungkar.

Penjelasan-penjelasan di atas menegaskan bahwa dalam membangun keluarga sakinah adalah dengan mengembalikan format pembinaan keluarga sesuai dengan masa Nabi Muhammad saw. Mengikuti Nabi tidak boleh dipilih-pilih secara parsial, ia harus diikuti secara keseluruhan, baik dari mulai fisik dengan menggunakan cela pada mata, bersiwak untuk gigi, memakai sorban di kepala, berjubah panjang, dan sebagainya.

Begitu juga dengan istri, ia harus mengikuti secara tradisional sesuai kehidupan para istri Rasulullah saw. Seperti menggunakan pakaian yang hitam panjang dan menggunakan cadar. Selain dari pada itu, istri yang tergabung dalam masturah juga harus mengikuti seluruh teks-

\footnotetext{
عن أنس رضي الله عنه: إذا أراد الله بأهل بيت فقّههم فالذّين ووقٌر صغيرهم 21 كبيرهم ورزقهم الرّزق فى معيشتهم والقصد في نفقاتهم وبصرهم عيوبهم فيتوامنها و إذا أرادبهم غير ذالك تركهم هملا.
} 
tualitas petunjuk Rasulullah Muhammad saw. yang termaktub di dalam hadis-hadis yang diriwayatkan oleh para perawi hadis dan dikutip kembali oleh para maulana-maulana yang menjadi panutan jamaah tablig. Seorang tidak boleh banyak bergaul dengan pihak luar selain muhrimnya. Untuk berbelanja kebutuhan rumah tangga pun suami yang menjalankannya. Istri hanya bertugas untuk mengurus anakanaknya dan kebutuhan suaminya. Dalil-dalil yang banyak digunakan untuk membina istri adalah dalil-dalil yang bersifat misoginis.

\section{Model Dakwah Jamaah Tablig dalam Membentuk Keluarga Sakinah}

Pembinaan keluarga sakinah bagi jamaah tablig tidaklah bersifat formal seperti yayasanyayasan dan tempat-tempat rehabilitasi yang hidup di kota-kota besar. Konsep pembinaan di dalam jemaah tablig bersifat tradisional dan dijalankan secara alamiah melalui khuruj fi sabilillah. Sebuah pembinaan yang dijalankan tanpa aturan-aturan khusus, tanpa pengarahan dari amir yang memimpin mereka untuk khuruj, namun mereka melihat dengan sendirinya keadaan dunia ini beserta orang-orang yang mengisinya, termasuk dirinya dan selanjutnya melalui jalan zikir ia mengingat seluruh kesalahan-kesalahannya dan bertaubat di jalan Allah Swt.

Metode yang dijalankan di dalam jamaah tablig merupakan formula terapi mental dan spiritual bagi siapapun yang terinfeksi virus duniawi dan berkelanjutan kepada terciptanya kesehatan jasmani dan rohani. Bahkan dengan semakin intensifnya keluarga yang sedang bermasalah dalam menjalankan terapinya di dalam kegiatan jamaah tablig maka semakin cepat pula jalan kesembuhan menyertainya, bahkan diikuti dengan kesehatan mental dan spritualnya.
Pada konteks ini, seorang keluarga yang sedang bermasalah akan diterapi secara alamiah di dalam kegiatan rutin jamaah tablig yang diawali dengan khuruj fi sabilillah selama tiga hari. Mereka akan mendapatkan pengetahuan agama dari yang awalnya hanya berguna secara personal hingga berguna untuk diterapkan di dalam rumah tangganya. Di sinilah pada akhirnya keluarga yang sedang bermasalah mampu untuk membangun kembali rumah tangganya menjadi sakinah, mawaddah dan rahmah.

Membangun kembali rumahtangga pasca problem rumah tangga tentunya akan mengalami kesulitan dalam menjalaninya, mengingat bahwa narkoba adalah candu yang dimungkinkan akan kembali digunakan bagi penggunanya ketika mentalnya kembali terpuruk. Untuk itu dibutuhkan kerja sama pihak ketiga, keempat, kelima, dan seterusnya untuk membangun mental penggunanya menjadi anti narkoba.

Ketika masa terapi dijalankan di dalam kegiatan khuruj selama tiga hari, akan diajarkan kepada mereka pondasi dakwah (ushul adda'wah) Islam yang harus menjadi pegangan utama para anggota jamaah, yakni:

1. Empat perkara yang diperbanyak:

a. Dakwah ila Allah; yakni dakwah ijtima'i, dakwah infiradi, dakwah 'umumi dan dakwah khushushi.

b. Ta'lim wal Ta'lum; yakni ta'lim infiradi, ta'lim ijtima'i, halaqah tajwid, ta'lim fadhilah 'amal dan mudzakarah sifatsifat sahabat.

c. Zikir Ibadah

1) Zikir : membaca Subhanallah, wal hamdulillah, walaa ilaaha illallaah, wallaahu akbar; shalawat, istighfar dan tilawah al-Quran.

2) Ibadah : Ibadah fardhu, wajib, sunnat dan mustahab. 
d. Khidmat; yakni khidmat kepada diri sendiri, rombongan jamaah, orang kampung dan amir jamaah.

2. Empat perkara yang dikurangi :

a. Kurangi masa makan dan minum.

b. Kurangi masa tidur dan istirahat.

c. Kurangi percakapan yang sia-sia.

d. Kurangi masa di luar masjid.

3. Empat perkara yang dijaga :

a. Mengutamakan amal ijtima'i daripada amal infiradi.

b. Ketaatan kepada amir jamaah, selama taat kepada Allah dan Rasul-Nya.

c. Kehormatan masjid.

d. Sabar dan tahamul (ketahanan dalam menghadapi ujian).

4. Empat perkara yang ditinggalkan :

a. Berharap (dalam hati) kepada makhluk, berharap hanya kepada Allah.

b. Meminta kepada makhluk, meminta hanya kepada Allah.

c. Ishraf (perbuatan boros atau mubazir).

d. Menggunakan barang orang lain tanpa izin.

5. Empat perkara yang tidak boleh disentuh :

a. Politik praktis dalam dan luar negeri.

b. Khilafiyah/perbedaan mazhab.

c. Aib masyarakat.

d. Status sosial, sumbangan dana dan derma.

6. Empat perkara yang dijauhkan :

a. Tankish (merendahkan).

b. Tankid (mengkritik).

c. Taqabbul (membanding-bandingkan).

d. Tardid (cepat menafikan atau menolak sama sekali).

7. Empat pilar (tiang/ dasar) agama :

a. Ahli dakwah (tablig, dai, juru dakwah).

b. Tadris (para ulama, pengasuh/mudir pondok pesantren/madrasah, majlis taklim). c. Kanka (mursyid, ahli tarekat) dan

d. Mushannif (para pengarang kitab).

Inilah konsep besar jamaah tablig dalam melakukan terapi batiniah dan jasmaniah bagi para keluarga yang bermasalah. Implikasi praktis dari khuruj tersebut pasca mengamalkan semua ketentuan-ketentuan di atas, yakni:

1. Mengetahui pentingnya agama Islam untuk menyelesaikan segala masalah.

2. Keimanan bertambah, ada kekuatan mengamalkan agama, agama dipraktikkan bukan hanya sekedar teori. Ajaran agama sejak bangun tidur sampai tidur kembali diamalkan.

3. Sifat lembut hati dan siap bekerja sama untuk kebaikan dengan siapa saja, kapan saja, dan di mana saja. Dalam satu jamaah, apabila kita ikut jamaah antarprovinsi, biasanya berbeda-beda suku dan sebelumnya tidak saling mengenal namun memiliki satu tujuan, yaitu memperbaiki keimanan dan memperbaiki diri (self help group). Sesama jamaah saling melayani untuk mendapatkan sifat rendah hati namun tidak rendah diri. Masing-masing melupakan status dan jabatan, semuanya sama dalam pandangan Allah.

4. Memiliki keberanian untuk bicara di depan orang banyak (public speaking), saling berbagi ilmu, saling menjaga.

5. Tidak boleh membicarakan aib, baik aib diri sendiri, aib orang lain, aib masyarakat, apalagi aib sesama jamaah. Tidak boleh membicarakan politik dan tidak boleh meminta sumbangan. Berusaha tidak memakai barang orang lain sekalipun sendal sesama jamaah.

6. Setiap pagi ada musyawarah pagi (morning meeting). Segala sesuatu harus berdasarkan musyawarah. Baik dalam memilih pemimpin atau siapa yang bertugas. Masing- 
masing mendapatkan tugas secara bergiliran dan bergantian. Ada tugas masak, tugas ceramah, tugas silaturahmi kepada para ulama, pemerintah, dan tokoh masyarakat setempat. Ini akan membentuk kebiasaan bermusyawarah terutama dengan anak istri di rumah.

7. Memiliki jiwa internasional. Bertemu sesama muslim dari seluruh dunia. Berpikiran global. Hilang keangkuhan memiliki ilmu atau harta yang banyak. Hilang rasa ingin disebut ulama dan dihormati.

8. Ada amalan intiqali (amalan ketika khuruj bersama jamaah/terapeutik community), ada amalan maqami (amalan ketika di daerah sendiri bersama warga sekitar dan keluarga/family therapy and couple support)

9. Harm Reduction (pengurangan dampak buruk) dan Demand Reduction (pengurangan permintaan narkoba) serta 12 Step Islami. Selain belajar memperbaiki diri juga belajar mengajak orang lain memperbaiki diri dengan cara yang lembut dan bertahap.

10. Dan banyak lagi manfaat bagi kesehatan fisik, mental dan lingkungan hidup kita apabila kita melaksanakan program ini dengan benar sesuai arahan.

Khuruj fi sabilillah diibaratkan muara tempat berkumpul air-jernih, keruh, kotor, dari gunung, dari kota, dari pedesaan, dan sebagainya dari berbagai sungai sebelum memasuki lautan. Semua program-program Islami dari jamaah-jamaah Islamiyah serta kaum muslimin dan muslimat dari berbagai latar belakang, status, dan profesi di seluruh dunia seperti ESQ La Tahzan, Quantum Ikhlas, MQ Syalafi, Sufi, ulama, pengusaha, militer, drug users, ODHA, dan lain-lain berkumpul dalam khuruj fi Sabilillah sebelum memasuki universalisme Islam dan persatuan kaum muslimin dan muslimat seluruh dunia.
Melalui jalan khuruj tersebut, setiap anggota keluarga yang bermasalah selain mampu merehabilitasi dirinya tapi juga mampu menempa diri untuk dapat bersikap arif dan bijak dalam berumah tangga demi menjaga keseimbangan rumah tangga menuju keluarga harmonis. Supaya tercipta rumah tangga yang harmonis, sebuah keluarga harus selalu menjaga keseimbangan di berbagai segi kehidupannya.

Keseimbangan tersebut bisa diawali dari suami istri sendiri yaitu selalu menjaga keseimbangan hak dan kewajiban di antara mereka. Sebagai suami yang telah ditempa melalui khuruj untuk menjadi personal yang saleh, maka menghormati hak dan memenuhi kewajiban kepada istri merupakan suatu kebahagiaan tersendiri karena dengan demikian akan memperoleh perlakuan yang sama dari istrinya.

Sebagai suami yang soleh seharusnya senantiasa melakukan yang terbaik bagi keluarganya, termasuk mengutamakan nafkah keluarga dalam membelanjakan hartanya di atas kepentingan-kepentingan yang lainnya. Suami juga hendaknya pandai-pandai membelanjakan hartanya, mana yang lebih penting itulah yang didahulukan.

Membelanjakan harta untuk sedekah di jalan Allah (termasuk untuk dakwah) adalah hal yang utama. Sehingga dengan doktrin agama yang seperti itu, akan mampu menekan kejiwaan para mantan pecandu narkoba untuk tidak kembali menggunakan harta keluarga pada pembelian barang-barang haram seperti narkoba. Sabda Rasulullah saw.:

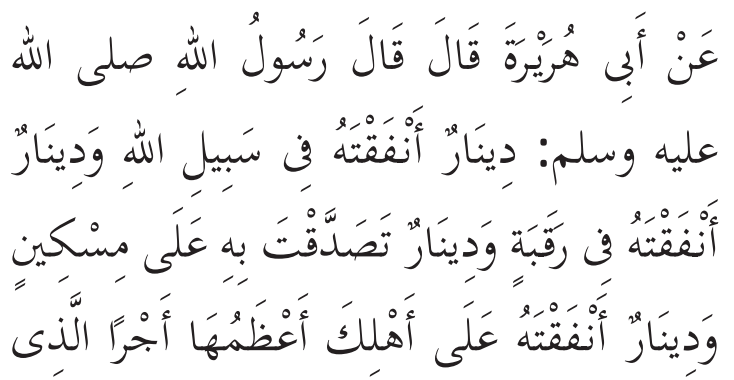




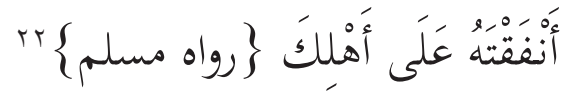

Artinya: "Satu dinar yang engkau nafkahkan di jalan Allah, satu dinar yang engaku nafkahkan untuk seorang budak, satu dinar yang engkau sedekahkan kepada seorang miskin, dan satu dinar yang engkau nafkahkan kepada keluargamu, maka sangat besar pahalanya yang mengaku nafkahkan kepada keluargamu." (HR. Muslim)

Sebagaimana yang telah disampaikan di awal kajian bahwa Allah Swt. telah menciptakan setiap makhluknya termasuk manusia itu berpasang-pasangan dengan tujuan supaya mereka (manusia) dapat berumah tangga dan menjadikan keluarganya menjadi sakinah mawaddah wa rahmah. Keluarga yang sakinah adalah keluarga yang tercukupi secara material maupun spiritualnya (zahir maupun batinnya).

Kedua kebutuhan tersebut harus diseimbangkan satu sama lainnya. Karena tidak akan tercipta ketenteraman rumah tangga jika salah satu unsurnya tidak terpenuhi. Seperti hadis yang disampaikan oleh Anas r.a., bahwasanya ketika Allah menghendaki suatu keluarga menjadi individu yang mengerti dan memahami agama, yang lebih tua menyayangi yang lebih kecil dan sebaliknya, memberi rezeki yang berkecukupan di dalam hidup mereka, tercapai setiap keinginannya, dan menghindarkan mereka dari segala cobaan, maka terciptalah sebuah keluarga yang dinamakan sakinah, mawaddah, wa rahmah. ${ }^{23}$

22 Abu al-Husain Muslim bin al-Hajjaj bin Muslim al-Qusyairi anNisaburi, al-Jami' ash-Shahih al-Musamma Shahih Muslim, (Beirut: Dar al-Jail wa Dar al-Afaq al-Jadidah, t.th.), Juz. 3, h. 78

23 Jalal ad-Din as-Suyuthi, Jami' al-Ahadits, (Beirut: Dar al-Kutub alIlmiyyah, t.th.), Juz. 2, h. 252. Teks hadis lengkapanya adalah:

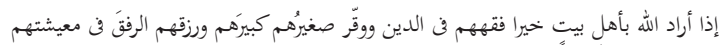

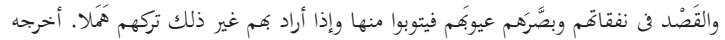

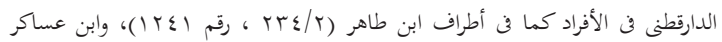

Selain kedua unsur itu, ada satu lagi unsur lain yang sangat mendukung akan terciptanya keluarga sakinah melalui telaahan terhadap perilaku dan konsep jamaah tablig. Unsur tersebut adalah terciptanya keharmonisan hubungan sosial, karena manusia tidak bisa hidup tanpa uluran tangan dari orang lain, sepintar dan sekaya apapun dia.

Manusia diciptakan di dunia sebagai mahluk sosial yang secara naluriah membutuhkan orang lain. Ia butuh saling mengenal satu sama lainnya sehingga terciptalah suasana tolongmenolong di antara mereka. Baik itu tolongmenolong dalam urusan dunia maupun tolongmenolong dalam urusan akhirat. Tolong-menolong dalam urusan dunia contoh konkretnya seperti adat gotong-royong dalam menyelesaikan suatu pekerjaan yang tidak bisa diselesaikan sendiri seperti membuat rumah atau yang lainnya. Sedangkan contoh tolong-menolong dalam urusan akhirat seperti amar makruf dan nahi mungkar, dari sinilah lahir konsep alkhuruj demi mengimplementasikan kehendak sosial tersebut.

Pada akhirnya harus diakui bahwa jamaah tablig mempunyai konsep keluarga sakinah tersendiri, yang pada dasarnya konsep tersebut bersumber dari hukum Islam meskipun dalam beberapa hal ada sedikit perbedaan dalam penafsirannya. Selain itu konsep tersebut juga tidak atau belum tertuang dalam sebuah konsensus sehingga pelaksanaannya pun belum seragam di antara anggotanya.

\section{Kesimpulan}

Konsep keluarga sakinah dalam komunitas jamaah tablig bersifat tradisional, di mana mereka memaknai dan mengimplementasikan teks-teks agama secara tekstual, sehingga suami menjadi sentral utama dalam keluarga dengan

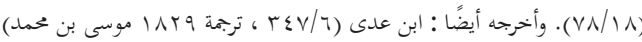


istri sebagai masyarakat kelas dua yang bertugas untuk mengurus rumah tangga dan anakanak. Mereka mengimani bahwa laki-lakilah yang harus memimpin di dalam rumah, sehingga istri harus tunduk dan patuh kepada suami secara mutlak. Istri yang biasa disebut dengan "masturah" menjalankan ajaran agama pula sesuai dengan bunyi asli dalil-dalil agama yang menjadi pegangan mereka. Jika mereka keluar dari makna tekstual maka dinggap telah tidak mengikuti jalan hidup Rasulullah Muhammad saw. beserta para sahabatnya.

Pada konteks ini, semua yang dilakukan istri selalu dibayang-bayangi oleh laknat, entah itu laknat alam, malaikat, maupun Allah. Tidak dapat dipungkiri kalau mereka masih sering menggunakan hadis-hadis yang berbau misoginis. Hal ini terjadi karena mereka berusaha untuk selalu konsisten menerapkan cara hidup yang hanya didasarkan dengan al-Quran dan al-hadis dan tidak begitu memperhitungkan kondisi sosial masyarakat yang ada sekarang ini.

\section{DAFTAR PUSTAKA}

Masyhur, Musthafa. Qudwah di jalan Dakwah, terjemah oleh Ali Hasan, Jakarta: Citra Islami Press, 1999.

Jabir, Husein bin Muhsin bin 'Ali. Membentuk Jama'atul Muslimin, alih bahasa oleh Supriyanto, Jakarta: Gema Insani Press, 1998.

Qowim, Muhammad, dkk. Model Dakwah Jama'ah Tablig, Laporan Penelitian Kelompok Mahasiswa Pasca Sarjana IAIN Sunan Kalijaga Yogyakarta, Yogyakarta: Perpustakaan Pasca Sarjana, 2002.

Anshari, Furqon Ahmad. Pedoman Bertablig Bagi Umat Islam, ed. Supriyanto Abdullah, Yogyakarta: Ash-Saff, 2000.
Ahmad, Abdurrahman. Petunjuk Sunnah dan Adab Sehari-hari Lengkap, Cirebon: Pustaka Nabawi, 2000.

al-Sajistani, Sulaiman bin al-Asy'ats Abu Dawud. Sunan Abi Dawud, Beirut: Dar al-Fikr, t.th. Zuhaili, Wahbah. Ushul al-Fiqh al-Islami, Damaskus: Dar al-Fikr, 1986.

al-Ma'ali, 'Abd al-Malik bin 'Abdullah bin Yusuf al-Juwaini Abu. al-Burhan fi Ushul al-Fiqh, Mesir: al-Wafa', $1418 \mathrm{H}$.

al-Ashbahi, Malik bin Anas Abu 'Abdillah. Muwaththa' al-Imam Malik, Damaskus: Dar al-Qalam, 1991.

al-Bukhari, Muhammad bin Isma'il Abu 'Abdillah.al-Jami'ash-Shahih al-Mukhtashar, Beirut: Dar Ibn Katsir, 1987.

Basyir, Ahmad Azhar. Hukum Perkawinan Islam, Yogyakarta: UII press, 1999.

Kauma, Fuad, \& Nipan. Membimbing Istri Mendampingi Suami, Yogyakarta: Mitra Pustaka, 2003.

Mubarak, Ali. Muhtasar Nailul Autar, Kairo: alMu'allaqat as-Salafiyah, $1374 \mathrm{H}$.

Hamidi, Muammal, dkk. Terjemahan Nailul Autar, Surabaya: PT bina Ilmu, 1993.

an-Nisaburi, Abu al-Husain Muslim bin al-Hajjaj bin Muslim al-Qusyairi. al-Jami' ash-Shahih al-Musamma Shahih Muslim, Beirut: Dar al-Jail wa Dar al-Afaq al-Jadidah, t.th. as-Suyuthi, Jalal ad-Din. Jami' al-Ahadis, Beirut: Dar al-Kutub al-Ilmiyyah, t.th. 